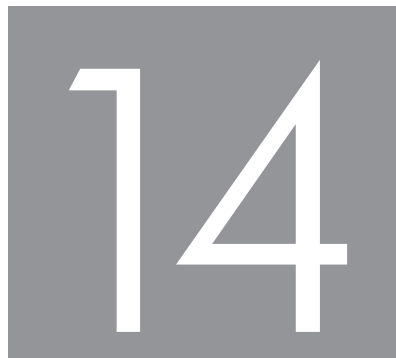

\title{
THE ENABLEMENT OF SERVICE LEARNING CHAMPIONS
}

\author{
RECIPROCAL KNOWLEDGE SHARING FOR \\ ENGAGEMENT BETWEEN THE THIRD SECTOR \\ AND HIGHER EDUCATION
}

Karen Venter \& Ielse Seale

\section{ABSTRACT}

While the remains of the apartheid legacy still challenge broader society, there are distinct possibilities for making constructive contributions when the third sector and higher education collaborate for democratic community engagement such as service learning. Knowledge sharing is a major driver in fighting social injustice in any society. Within our service learning community, which included partnerships that consisted of participants from the third sector, the higher education sector, the community sector and the global scholarly sector, we identified champions who were willing to 'rock the boat' in efforts to achieve societal change through reciprocal knowledge sharing. A qualitative research design within the constructivist paradigm was utilised. Semistructured interviews were used to determine who the champions were and to explore the perceptions of the identified champions regarding the role of knowledge sharing in their development and enablement. We constructed a suggested framework of principles to guide the knowledge sharing process among current and future champions for the pedagogy of service learning. 


\section{INTRODUCTION AND BACKGROUND}

Knowledge sharing between organised civil society (ie the third sector) and higher education is essential promoting community engagement. Community engagement became an integral part of higher education. Since 1999, community engagement has been implemented as one of the three core functions (with teaching and research) to enable transformation in higher education (Hall 2010:1). The appeal for social and educational change now urges scholars to determine whether engagement between communities and higher education institutions ( $\mathrm{HEls}$ ) has advanced social and educational transformation (Albertyn \& Daniels 2009:409; Hlengwa 2010:1; Stanton \& Erasmus 2013:75). Through engaging with communities, researchers should aim to explore the value of community engagement as a crucial part of the South African research agenda (Hall 2010:27; Stanton \& Erasmus 2013:84).

Community engagement has infused the teaching and research functions of academics within the ivory towers of HEls with an expanded sense of context, relevance and application towards engagement. Academics are now urged and compelled to step out and connect with society. Community engagement as a scholarly activity is of critical importance in promoting dialogue through knowledge sharing between the various sectors of society and HEls. For the purposes of this book the focus is on engagement between the third sector and higher education in producing knowledge that is relevant and useful in the South African context. Through a "scholarship of engagement" (Boyer 1996:148), academics and their external partners can create a partnership climate and collaborative space in which non-profit organisations of the third sector, HEls and communities can share knowledge.

Service learning (SL), as a pedagogical strategy and curricular form of community engagement, facilitates the integration of community service with teaching and learning (Furco 2001:67; UFS 2006). The educational philosophy of SL is valueladen, synergist, dynamic, and highly complex, and enables individual and social change (Shumer 2000:77); therefore, SL researchers are challenged to find innovative ways of exploring the influence of SL on personal, social and academic learning development of students. In addition, enhancing the value of SL for HE staff and external participants also needs ongoing, focused attention from all concerned.

The study reported in this chapter was conducted within a SL community at the University of the Free State (UFS) where SL was influenced by global SL pioneers. Our SL community consisted of various groups who share knowledge within established SL partnerships, namely the non-profit arena within the third sector, the higher education sector and the community sector. A fourth group, the global scholarly sector, is included in this SL community to allow for benchmarking against 
the expert champion voices. Within these partnerships, academic SL was used as an educational tool to facilitate reflective knowledge sharing in order to develop globally responsible citizens working towards social and educational enhancement at the local level. Leaders in the mentioned groups were identified as champions who tend to 'rock the boat' in an attempt to achieve societal change for the common good of society (Narayanan 2010). These passionate and committed leaders act as champions for SL and serve as role models for others in the SL field (Jordaan 2013:221). Champions seem to play a crucial role in the SL community. Erasmus (2007:1 10) points out that the champions of SL work "not only at the chalkboard but also at the coalface most of the time" as they "dare to venture into the - for South Africa - unchartered waters" of SL. We understand that knowledge sharing takes place within a partnership context; however, there seems to be a dearth in the literature regarding the role of knowledge sharing in the development and enablement of champions for SL. Therefore the aim of the study was to gain a better understanding of the role that knowledge sharing has played in the development of champions.

Thus, we argue that a better understanding of principles to guide the knowledge sharing process could contribute to the development and enablement of current and future champions for active engagement between the third sector and higher education. We set out to determine who the champions in our SL partnership were. We explored the perceptions of the identified champions regarding the role of knowledge sharing in their development and enablement as champions for SL and identified principles to guide the knowledge sharing process.

Rather than presenting a theoretical framework, findings are integrated with a discussion of literature related to knowledge sharing for the development and enablement of SL champions. We introduce the context of the study, which is followed by the methodology and the findings from the data generated through semi-structured interviews. The chapter concludes with recommended principles to guide the knowledge sharing process between the third and higher education sectors, as well as with suggestions for future research.

\section{CONTEXT}

Within our SL community, the non-profit arena within the third sector, the higher education sector, the community sector and - from a distance - the global scholarly sector collaborated in democratic engagement through reciprocal knowledge sharing (see Figure 14.1). 


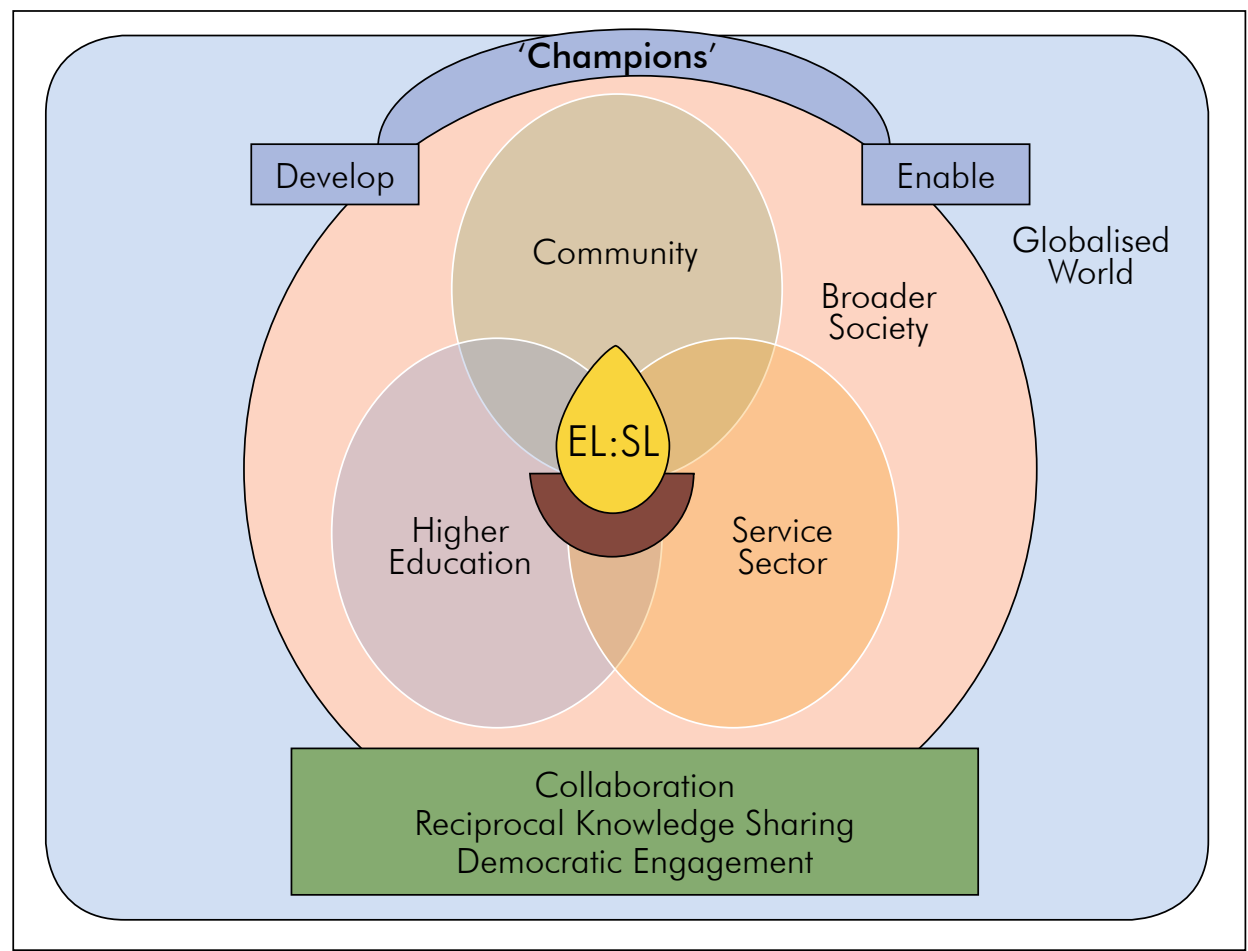

FIGURE 14.1 Broad context of the study

We used SL as a form of experiential learning (EL) to facilitate community engagement. Through reflective discussion we identified a definition of SL champions from participants from the four sectors. The contention was that champions developed and were enabled through reciprocal knowledge sharing to act as change agents who try to solve personal and societal challenges in broader society and the global world.

On a micro-level the study was conducted within a specific SL partnership context where professional nurses further their studies in nursing education at the UFS. The study population involved SL champions from the four sectors. This SL community reflected the well-known triad partnership model which was adapted to include the global SL champion community (Bender, Daniels, Lazarus, Naudé and Sattar 2006:93). However, for the purpose of this chapter we mainly report on the findings of the NPO voices as representatives of local communities as guided by literature urging researchers to get closer to the community voice (Alperstein 2007:59; Du Plessis \& Van Dyk 2013:62, 73; Nduna 2007:69). The voice of one female academic engagement pioneer within our existing partnership was added, because this pioneer is an NPO member who has been actively engaged in NPO activities 
and is an academic who serves at our HEI. Voices of global pioneers are added for benchmarking purposes.

Students and academics from the higher education sector participated in academic service activities aimed at addressing identified learning needs (mostly health and education related issues) of volunteer care workers who rendered service at various NPOs within the third sector. Thereafter, volunteer care workers shared their coconstructed knowledge among their own communities. Eventually, partners from all the sectors reflected on the SL experiences in order to gain a deeper understanding of the linkage between academic content and community dynamics, as stipulated in the Community Service Policy of the UFS (UFS 2006:9).

\section{METHODOLOGY}

A qualitative research design, within the constructivist paradigm, was used (Mertens 2010:11, 226). Participants for the study were purposefully selected (Mertens 2010:320) to represent all the groups within our SL community. The sample included champions from four groupings: three leaders from the third (NPO) sector, one community representative, four SL academics (including an academic community engagement pioneer and two nursing education students from the UFS), as well as five scholarly pioneers who were interviewed during a SL conference abroad. The voice of one female academic engagement pioneer within our existing partnerships was added, because this pioneer is an NPO member who has been actively engaged in NPO activities and is an academic who serves at our HEI.

Qualitative data were collected through semi-structured interviews. A step-by-step analysis was conducted as advised by Mertens (2010:424-426). During the first step, all the data was reviewed and transcribed. Steps two and three occurred in synergy where data were explored and reduced. Initial and focused coding was done and the data were sifted. After focused coding was conducted, a framework for a layout of the reporting of the study was planned. Categories, themes and subthemes of the analysed data were identified. Credibility of the analysed data was ensured through member checking (with research participants) and peer debriefing (with two other researchers) (Mertens 2010:431, 257). Thereafter, the data were interpreted. Data triangulation involved the inclusion of perceptions from a diverse representation, where even the voices of the least empowered were not lost. Semistructured interviews were conducted with identified champions who represent the third sector and the community (Mertens 2010:429). To ensure rigour, the principles for ethical practice (axiology) of qualitative research were followed as 
advised in literature (Mertens 2010:16-18). Practice of privacy, informed consent, confidentiality, honesty, no harm and the maintenance of ethical standards were respected (Chapdelaine, Ruiz, Warchal \& Wells 2005:10-11). Ethical clearance was granted for the study by the Ethics Board of the Faculty of Education at the UFS.

The findings of the study will now be discussed and integrated with related literature.

\section{FINDINGS}

The findings are organised into three categories related to the research questions, namely SL champions, knowledge sharing and principles to guide the knowledge sharing process. We report on the data gathered from three NPO organisations from the third sector, and one female academic engagement pioneer within our existing partnerships. The data from the five expert champions - hereafter called global pioneers (GP) - in the global scholarly sector are included to benchmark the findings of the other participants. Their data are included at the end of each section.

To indicate which participant is the source of the verbatim quotation gained from semi-structured interviews, the referencing system used is P1, P2 and P3 for the NPO participants and P4 for the academic engagement pioneer. Translated quotes are indicated with a ${ }^{*}$. For the global pioneers we use GP1, GP2, GP3, and so forth.

\subsection{Service learning champions}

The idea of SL champions has gained attention in the last few years (Erasmus 2007:110, 123; Jordaan 2013:221). They portray certain skills and personal characteristics that distinguish them from others, through which they take action and lead others in society. In being asked who the champions were, the participants did not only refer to the identified champions in their partnership context but presented defining characteristics as well.

\subsubsection{Partnership context}

The participants identified champions from the third sector, the higher education sector, and the community. Within the third sector, volunteer care workers in NPOs were identified as champions: "Caregivers in the organisations are the champions, because they have the practical knowledge to take care of the community" (P2).

In the higher education sector, academics and students were identified as champions: "The fuse in the gunpowder barrel was literally Professor (A). Other people who made an actual impact were students" $\left(P 1^{*} t\right)$. Champions were described as "people from 
the higher education institutions that are designing programmes" (P4). Champions also come from the community:

Without the community itself, one would not be able to implement those programmes and there are community members themselves that share and use knowledge. You need key people that will drive the work in the community those would be people that are already participating in programmes (P4).

In summary, one participant stated:

[E]verybody can be a champion, it all depends on how far the person is involved, how knowledgeable the person is and, to be more specific, how prepared the person is to share knowledge. Everybody has knowledge - but you can only identify a champion from what the champion would be doing with it - in this case how far a person is able to share the knowledge; what type of knowledge that is and the benefit that comes out of that knowledge (P4).

In comparison to the other participants, the global pioneers also identified champions from the entire SL community. They also mentioned various names that represent early as well as young and upcoming academic pioneers in the SL field. The following was voiced by one of our global champions:

There may be big champions that have more profile, but everybody is a champion in their own backyard, and their own context. So if somebody in a small village in SA is making some change, they're a champion. That is where the difference is made, not in the university classroom, not at the conference level, or when you are giving a keynote address, but when somebody does something with it. The local champions - they may do it in partnership with some bigger champions, but you always need the local champion. You can never do it without the local champion (GP1).

After identification of champions, the second aspect, namely defining characteristics of a champion, is addressed.

\subsubsection{Defining characteristics}

The participants spontaneously elaborated on the defining characteristics of SL champions. According to the participants, the champions adhered to an excellent standard of practice which portrayed characteristics of high levels of self-development. The champions rendered SL practice through a 'whole person approach' that surpassed the behaviour of other groups of people in the partnerships.

Champions have the ability to adapt to a situation; answer to a calling; care; commit themselves fully (with their heart and soul); co-create knowledge; persevere; serve beyond duty; share knowledge and expertise; and take responsibility towards the transformation of society (summary $\mathrm{Pl}-4$ ). The champions portrayed a positive attitude in their SL practice, because they were deeply devoted, fair, friendly, honest, 
passionate, patient, trustworthy, stable, humane, positive, loving, loyal and show integrity towards others. They committed themselves to lifelong learning in order to gain knowledge and share it with other citizens (summary P1-4).

We can thus reason that champions used a 'whole person approach' within their SL practice, while others merely observed everyday social and educational challenges in society such as poverty and the quest for widened educational access. The champions took responsibility and acted as change agents.

Another characteristic that gained attention was the self-development level of the champions. The participants revealed that the self-development level of the champions displayed aspects of excellence. The self-development level of the champions displayed selflessness, self-confidence, humble self-pride and self-respect (summary $\mathrm{P} 1$-4). Therefore we argue that the champions possessed a positive personal selfconcept, positive social self-concept and high self-ideal. Again, to benchmark our findings, one of the global pioneers noted: "I was 'star struck' by them! They were just so welcoming and there was just this sense of: This is an important field and we're all moving forward in this together" (GP3).

The next category of our report relates to knowledge sharing within a SL community.

\subsection{Knowledge sharing}

Knowledge sharing is defined as a process of exchanging knowledge, skills, experience and understanding among different people (Tsui, Chapman, Schnirer \& Stewart 2006:5). Our SL community provided an arena for such knowledge exchange, where the various groups shared knowledge, skills and experience.

Within the constructivist paradigm (Vygotsky 1978) the knowledge, ideas, attitudes and values within our SL community were shaped through democratic knowledge sharing among adult learners. Adults are self-directed learners (Knowles 1990). They gain learning from experience, mostly through solving problems. In real life, adult learning is self-directed towards coping with everyday life challenges. An adult wants to use new knowledge and skills right away in solving real-life issues (Hughes \& Quinn 2013:23). We mentioned earlier that we used SL as a form of experiential learning in the study. Dewey (1963) described the importance of experience in knowledge sharing (learning). He integrated theory and practice through emphasising the use of reflection on action, and also proposed that learning is a social process, hence leading to individual and social transformation. In line with the thoughts of Dewey, learning is seen as being developmental and that good citizenship rests on knowledge sharing (Eyler \& Giles 1994). 
As mentioned previously, we noted in our study that knowledge sharing developed the SL champions as 'whole persons'. Current learning and brain-based research found that experiential learning engages the 'whole brain'. A recent study done by Nwokah and Leafblad (2013:92) found that SL, as a form of experiential learning, is one of the best ways to enhance 'whole brain' learning. They found that by providing challenges in real life, the whole brain was used to solve given challenges. The participants in our study revealed that SL champions could adapt to a situation, answer to a calling, care, commit themselves fully (with their heart and soul), cocreate and share knowledge, persevere, serve beyond duty, share expertise and take responsibility towards the transformation of society (summary P1-4). These responses provide evidence regarding the development of the 'whole brain' of a SL champion who shares knowledge and solves problems through a 'whole person approach'.

As engaged scholars in our SL community, we realised that we have co-constructed our own approach to knowledge sharing (as an element of learning). The approach invoked philosophical ideas linked to various well-known learning theories such as the adult learning theory (Knowles 1990), behaviourism (Skinner 1971), cognitivism (Piaget \& Inhelder 1969), constructivism (Vygotsky 1978) and critical social theory (Merriam \& Caffarella 1999:340). Our approach evolved into a possible 'relational learning philosophy' and is currently defined as follows:

In our SL community, knowledge sharing is an interactive process in a socially and culturally diverse context characterised by a collaborative, reciprocal, symbiotic partnership, driven by development and enablement of human abilities as reward.

Based on this philosophy, it was important to gain an understanding of the role that knowledge sharing played in the development and enablement of the knowledge sharers on themselves and others in their immediate community.

\subsubsection{Role of knowledge sharing}

Knowledge sharing developed and enabled the champions to become responsible citizens. The acquired skills empowered the champions to become change agents who focus on solving real-life challenges in society. As a result of knowledge sharing, even the quality of the partnerships developed into a higher level of sustainability.

The role of knowledge sharing was categorised into two main themes: firstly, the development and enablement, and secondly the empowerment of champions. 


\subsubsection{Development and enablement of SL champions}

Development and enablement of champions were classified under educational and human development as two subthemes that directed the knowledge sharing in our SL community.

In the introduction of the chapter, we stated that HEls are compelled to create a learning environment which will facilitate the educational development and enablement of lifelong learning skills (Daniels 2013:193; Marjan \& Peyman 2012:399). Therefore, lifelong learning skills were a focus area in our SL community, in order to develop and enable SL champions. These skills included critical thinking, analytical skills, communication, teamwork, and problem solving (Tempone \& Martin 2000:3).

As a lifelong learner, a SL champion has the ability to integrate theory and practice: "Knowledge sharing develops and enables champions to connect academic knowledge and practical experience" (P2). Champions show expertise and are knowledgeable: "A champion has experience and knowledge of their field" (P3*t). Thereby a SL champion uses the whole brain as a cognitive knower to share knowledge. The findings regarding the SL practice and characteristics of the champions not only serve as evidence for the cognitive domain, but include the affective (attitude) and psychomotor (skills). It thus engages the whole person as referred to by Bloom (Hughes \& Quinn 2013:107).

Human development of champions is evidenced by a change in their self-development and their ability to initiate social development. Self-development is depicted in the ability of a champion to change his or her behaviour:

There should be change in a person. When a champion's personality, their attitude, their way of thinking and their emotions change, those are the things that will indicate to us whether there is development or not. Champions should prepare themselves for the unknown within reality (P4).

With the focus on self-development, SL develops the personal, intrapersonal, interpersonal and social responsibility of citizens (as evidenced in a study done by McMillan 2013:50, 51). SL has the potential to influence a person's 'being' (McMillan 2013:34). The literature reports about development in students on personal, intrapersonal and interpersonal levels (Eyler \& Giles 1999). In the light of knowledge sharing within our SL community, the same would apply to the personal transformation of identified champions. Therefore, they also developed the ability to initiate the social development of others in their immediate society. Social development is evidenced by the influence of knowledge sharing on social transformation in the following quote: 
I think it satisfies those needs of one to share your knowledge and experience with others. There are three things that result from knowledge sharing: You grow in knowledge, and you learn to understand more about yourself -your response to people whom you serve - you learn to understand other people (P3).

Therefore, we posit that knowledge sharing influenced the champions to care about and contribute to the development of other human beings in society. Our champions understood and observed the influence of previous oppression and injustices from the past on society. They aimed to contribute to the development of the previously oppressed in society. The critical social theory validates our assumption regarding social development initiated by SL champions (Merriam \& Caffarella 1999:340). This theory places emphasis on the role of the broader society in knowledge sharing, in order to develop a sustainable society. The goal of the champions was therefore to change society to a sustainable place for themselves and others in society; their wisdom became the solution and hope for those in despair.

The third subtheme that was classified was barriers in development relating to social justice. One of the participants voiced that "you should know how it feels to be poor and have a vision to leave the circumstances of poverty. Education is the route out of poverty" (P2). Participant 1 advised that "We should not share knowledge in one direction". Participant 4 agreed that there should be balance in knowledge sharing: "We should have an equilibrium which actually says we need each other: I can't do it without you and you can't do it without me". Participant 2 summarised the enabling solution towards social injustice with two words: "reciprocal empowerment". Thus in our SL community we strove to render SL practice towards eliminating social injustice within our partnership context.

The last subtheme, classified under development and enablement of champions, was SL partnership development. To strengthen the argument of social justice, a champion voiced evidence of educational and human development: "The contribution of academics in the partnership was of immense value to us. They share their occupational experience and academic knowledge in a practical way with the community" (P1*t). Additionally, Participant 2 suggested: "Even if you are not with the others anymore, the legacy of the knowledge that you share should stay with them". Therefore one of our key challenges is to build sustainable partnerships that reflect knowledge sharing and mutual respect for each other. Sustainability of partnerships can be safeguarded through quality assurance indicators (Bender et al 2006:92-1 11). Quality indicators of effective SL partnerships include collaboration, maintenance, monitoring and evaluation, the future of the partnership and sharing through celebration. 
Collaboration is the key quality indicator of partnerships. Roles, benefits and expectations are clarified by means of written memoranda of understanding. However, within partnerships there is an element of relationship building that does not only focus on operational matters. Participant 1 indicated the heart of collaboration: "They did not only do it out of their obligation as lecturers or out of charity, they connected with us at a much deeper level because they displayed humanity and caring, they poured their heart and soul in the project" (P1 *t). In this sense we agree with Bringle, Clayton and Price (2009) that partnership relationships possess qualities such as closeness, equity and integrity.

Maintenance as a quality indicator can build trust among the partners through informal communication. Formal communication such as regular meetings with the service sector and community representatives must take place on an ongoing basis. Participant 4 referred to the importance of reciprocal trust and honesty to maintain relationships.

Monitoring and evaluation of the impact of knowledge sharing should be done rigorously through analysis of artefacts (eg minutes of meetings). Participant 3 mentioned the importance of continuous feedback regarding the SL project outcomes and stated: "The university must not be scared to terminate a partnership if partners do not reach their outcomes and if the partnership does not thrive". Results can be utilised to plan the expansion or discontinuation of the partnership in time for the next cycle.

The value of celebration must not be underestimated as seen in the following quote: "I don't know how we are going to thank them; it is as if friendships developed and that was so precious. It is as if they were angels sent from heaven" (PI*t). It is clear that celebration as a formal appreciation and showcasing event, or as an ongoing event, is irreplaceable. Celebratory events facilitate deepened relationships and closure and provide an opportunity to network through discussion and reflection to shape the future.

The use of quality indicators can foster an enriched SL experience for partners within stable, flourishing partnerships embedded in an educational environment. We experienced that knowledge sharing in our SL partnerships contributed to the development of the partnerships at a deeper level. At the onset of our partnerships, all the sectors in the partnerships agreed to take responsibility as co-servers, co-learners and co-educators who engaged in relevant SL activities, therefore modelling democratic engagement is a fundamental aspect of SL pedagogy (Bender et al 2006:1-12, 31 , 92-111). A participant commented that "our partnership developed into a deeper level. We developed friendships and that was very precious to me" $\left(\mathrm{Pl}^{*} \mathrm{t}\right)$. 
The second theme that was classified under the role of knowledge sharing was the empowerment of SL champions.

\subsubsection{Empowerment}

Knowledge sharing empowered the SL champions to become change agents towards educational equality, respect for human rights and sustainable community development as enablers towards empowerment. A champion believes that knowledge sharing is empowerment. The next subtheme of empowerment emphasises the importance of educational equality in a previously oppressed society:

There is an old saying that states: Knowledge is power. If that power is transferred to the community, it would enable massive transformation. The previous years of oppression made us feel powerless. Knowledge empowered us to feel in control, because we could do something about the situation. You feel important, needed. However, I am sure this should not have been the case if we were not empowered with the necessary reciprocal 'free of charge' knowledge sharing within the relationship that we built with the university. Knowledge sharing prepared us to implement our knowledge in the community. That was more empowering than receiving money ... You should do something, even if it is small and seems insignificant, to initiate change in the correct direction to solve a problem $\left(\mathrm{P}^{*}{ }^{*}\right)$.

Knowledge sharing brings empowerment, in a lot of ways - on a personal, educational and on a social level. I can take the knowledge and also empower my champions and it makes you a better person. My knowledge that I share within myself is coping. Knowledge makes me cope; the fact that I can know how to cope empowers me. (P2)

We used SL to create academic learning experiences in which students participated in service activities which were aimed at addressing identified service needs in community. For example, partners from all the sectors reflected on the service and learning experiences regarding health related issues, in order to gain a deeper understanding of the linkage between academic content and community dynamics. In essence, SL balanced service to society with academic learning in order to mobilise the champions, as advised by literature (Furco 2001). Community engagement has infused the teaching and research functions of academics within the ivory towers of HEls, with an expanded sense of context, relevance and application towards engagement. As a higher education sector, we connected with the community.

Human rights equality emerged as another subtheme under empowerment of SL champions. A champion argued that we should understand the effect of oppression on society. This is illustrated by the following quote: 
There are definitely human feelings involved. I must say that knowledge sharing has really helped us as an organisation to heal in that respect. At the beginning we were antagonistic and worried, because we obviously come from an age where we are biased in our thinking. We were impressed about the way that the academic staff and students connected with us. There were no biases and assumptions that we will get hurt in the process. We could literally bury our old cows in the trench. I think SL has a very important role to play to promote diversity at the university. To place students of different groups in a diverse community is better than to sit in a class and theorise about these issues $\left(\mathrm{P} 1^{*}+\right)$.

Thus, we used dialogue through knowledge sharing between the third sector and higher education and aimed through this study to co-generate knowledge that is relevant and useful in the South African SL context. The goal of the collaboration went beyond the technical or individual development focus of most community projects, instead our goal was to focus on democratic engagement and lasting social change. It was important to one of the champions that his knowledge sharing should lead to sustainable changes:

We should transfer the knowledge in such a way, that even when the project comes to an end - that the effect of knowledge sharing will remain successful, ongoing and sustainable. It is important that constructive tools are transferred towards the empowerment of the community $\left(\mathrm{P} 1^{*}+\right)$.

The acquired skills empowered the champions to become change agents who dream and visualise society as a place where equal access to education, respect for human rights, sustainable community development, and eventual global sustainability exist.

We want to go a step further and propose that cultural harmony or congruence, policy driven community engagement and the internet can be powerful enablers towards sustainable societal development. Striving towards cultural congruency could enable citizens to overcome the hurt from the past and empower the community. Thus, we suggest that cultural congruence could be a possible enabler towards social transformation. The dynamics within the learning community speak of an appreciation of diversity of culture and sensitivity for social differences.

The last subtheme connected to empowerment relates to sustainable community development. The White Paper for Post-School Education and Training (RSA DHET 2014:39) states that many of the community engagement initiatives that are conducted by HEls are fragmented. In our opinion these initiatives cannot be measured as academic research projects. Thus future policies should aim to shape community engagement that leads to measurable community development through the integration of academic projects with research and community engagement. One of the policy objectives of this White Paper (RSA DHET 2014:39) states that 
higher education should be responsive to the needs of individual citizens, employers in the public and the private sector, as well as broader societal and developmental objectives. Therefore, we should aim to meet these objectives.

One of the global pioneers emphasised the sharing effect in the development of champions: "I think the most important part of knowledge sharing is making other people aware of your experiences and your insights" (GP1).

Another global champion explained the dynamic influence of the SL field on the development of champions:

I think that knowledge sharing is both the biggest problem that SL can have and it is also the biggest opportunity. The knowledge sharing was always in one direction, from the experts at the university to the people in the community. So, $S L$, when it is done well, is knowledge sharing in two directions that we should honour. There was a whole community of knowledge out there that the literature didn't show (GP2).

Another global champion voiced the role of knowledge sharing as follows:

So the champions shaped my thinking around SL and made me feel as though there was something there in terms of my intuition that - this is something that I am excited about and there is actually a group of people thinking about it (GP3).

We learned from one of the global pioneers that the community plays an important role in the development of others in the SL field:

What we do in SL is all about the community; how we can integrate what we have learned from the community with community and to the community. I think SL is not talking about ourselves; it's talking about how we can share our knowledge. And then we create knowledge together (GP4).

The following section deals with principles to guide the knowledge sharing process.

\subsection{Principles to guide the knowledge sharing process}

The last category of the findings is that of principles to guide the knowledge sharing process.

We argued that if we understand the role of knowledge sharing among the champions within the SL community, it could contribute to the quality of current and future engagement between the third sector and higher education. Our knowledge sharing took place within a partnership context. Therefore, it is important to use the advice of the champions in order to establish quality knowledge sharing (See Textbox 1 for summary of quotes). 
TEXTBOX 1 Third sector champions: Advice for quality knowledge sharing

- Start a relationship

- Do value clarification and work towards shared values

- Do a learning need analysis and clarify a common goal

- Have a mentor

- Share knowledge in different contexts: public, mentorship-apprenticeship

- Share your expertise

- Share guidelines to integrate theory and practice

- There should be balance in knowledge sharing

- Just use me as example, as a guide to create your own knowledge

- Act out knowledge to enhance change

- Evaluate the effect of knowledge sharing on sharer and recipient

- Evaluate the outcomes of set goals

- Recognise contribution

We used the findings of the study to shape our thinking, as advised by the third sector champions, literature and through reflection on our scholarship of engagement. Based on our co-constructed 'relational learning philosophy' we drafted our suggested conceptual framework of principles to guide the knowledge sharing process as illustrated in Figure 14.2.

If the knowledge sharing process in a SL community is guided by three main principles, namely connection, collaboration and continuous communication, it could lead to change towards reciprocal empowerment between the third sector and higher education. Connection entails the establishment of a SL network, either in the public domain or on a mentor-apprentice basis. The foundation of collaboration should be reciprocity and mutuality. Continuous communication through monitoring and evaluation shapes the knowledge sharing process where recognition of the knowledge contribution rewards all sectors in the SL community. The process can either continue if goals were not met, or can lead to reciprocal empowerment after change took place towards social justice for all in society. Therefore, these principles could initiate change towards the empowerment of a SL community characterised by mutuality and reciprocity between the third sector and HEls. If we apply the suggested principles, we could then have the ability to build, share and utilise knowledge for mutual enablement and capacity building. Of essence is that we should all take responsibility to act as change agents towards the transformation of education, by 
respecting human rights to work towards a sustainable society. Eventually, we can therefore contribute to global sustainability.

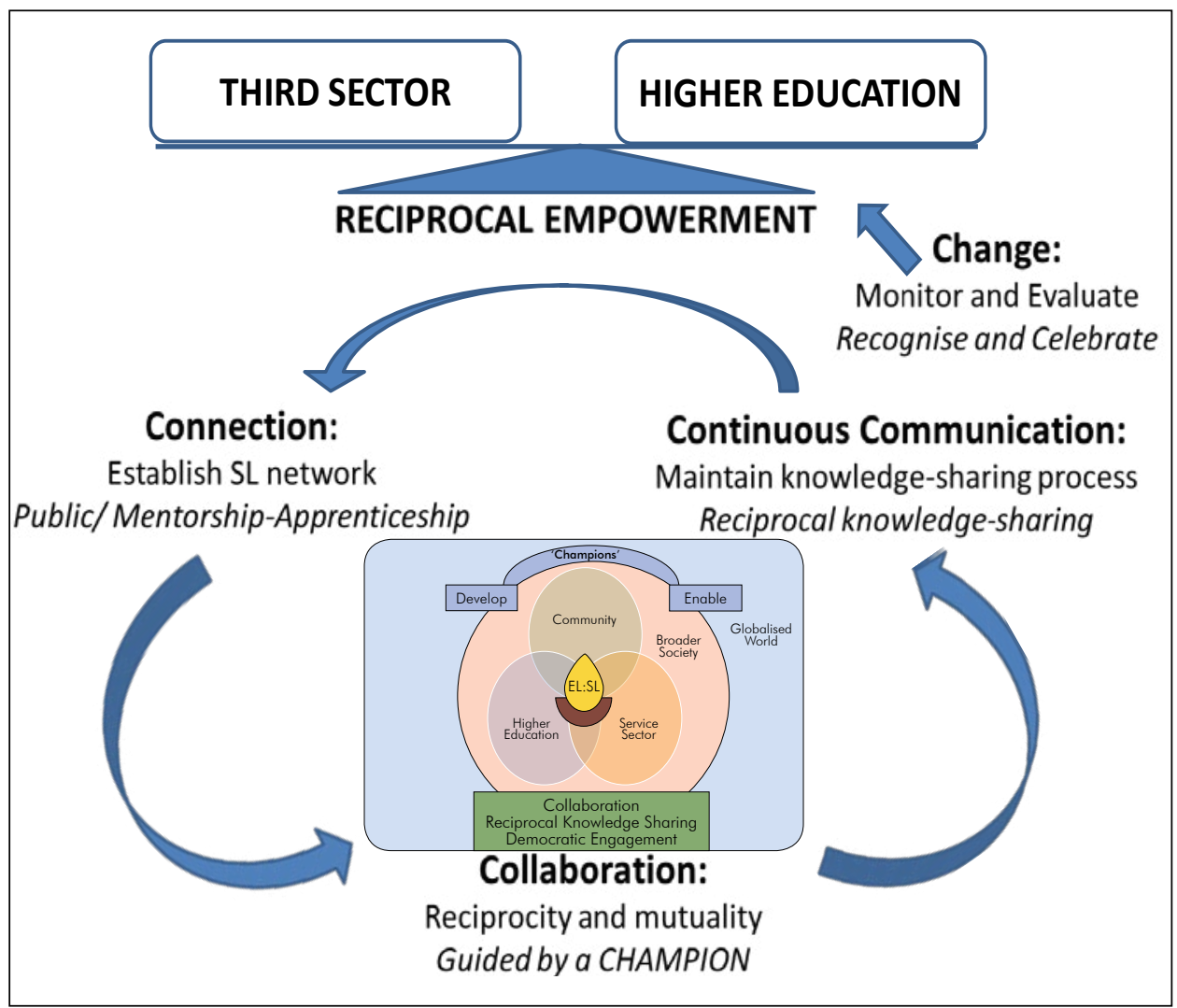

FIGURE 14.2 Conceptual framework of suggested principles

It was important to benchmark our findings regarding principles to guide the knowledge sharing process, because the global champions set the example by showing integrity and exceptional commitment in their practice. This was transferred from early pioneers to a younger generation. The following is a summary of their perceptions:

So the question people were asking was: How did you survive? How did you improve your practice? And every single person answered: Because we have a network. It was a sharing network, a knowledge sharing network (GP5).

Try to connect higher education, secondary education and community by sharing a topic. We need to learn from young people, they share knowledge from the international context (GP1). 
We can have a local network, from local network we can have a regional network, and from regional network we can have an international network, somehow if we can make it a systematic development that will be very good for SL stakeholders (GP4).

We have to verify community knowledge and incorporate it into our own scholarship. The new knowledge we're producing is a synthesis of academic knowledge and community knowledge. So it is a co-production of knowledge (GP2).

There was earnestness. I think we hear more depth of knowledge sharing when that genuine connection is made. It's not superficial. It gets to a point of mentorship-apprenticeship kind of relationship that is going to stay for a long time (GP3).

\section{CONCLUSION}

We listened to the voices from the third sector and benchmarked our findings in relation to the perceptions of global pioneers, to gain a better understanding of who the champions in our service learning community are. They believe that champions can be found in the third sector, the higher education institutions and the community sector. It was clear that champions have distinct defining characteristics whereby they establish themselves as champions. A picture of a champion reflects an image of excellence; when champions participate in knowledge sharing, the service of champions surpasses those of others. They conduct service learning practices as a whole person and display characteristics that speak of excellence. They are inherently motivated to participate in knowledge sharing, driven by specific educational needs for the sake of social transformation. They also engage in knowledge sharing for the love of learning. Their participation in knowledge sharing leads to societal change and personal growth. When they deal with pressing challenges in society, they rely on their previous experience and shared knowledge.

When applying the recommended principles based on the voices of the champions in an attempt to overcome barriers that hinder the knowledge sharing process, we can contribute to the development and enablement of current and future champions for active engagement between the third sector and higher education. A global champion noted the following:

So to me they were the champions because they were really kind of lighting the path and welcoming people in the field. And I think to me, that's what is so important and I think that stayed with me too, as my own professional development has advanced and grown and deepened. I will never forget that, and so when people come into the field I feel that that is one of my responsibilities to say: "Come into the fray and join us and be part of this" (GP3). 
Therefore, both the third sector and the higher education sector can share knowledge and expertise, with an integration of theory and practice from a shared 'knowledge

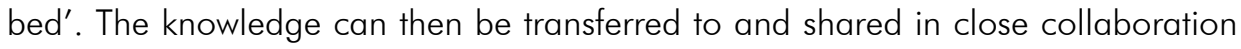
with the community sector.

We gained a better understanding of principles to guide the knowledge sharing process based on our democratic engagement and listening to the advice of champions in our context. Our suggested conceptual framework could enable reciprocal empowerment in this sector. The findings of the study reported in this chapter contribute to the fields of community engagement and service learning with an authentic South African identity.

If we use the advice of a global champion, we will carry the knowledge torch in the correct direction:

I guess I would say that the research that you are doing now - to embrace the concept of service learning to study knowledge sharing and make knowledge sharing more broad-based, not just to modern champions but to treat all of the people doing this as champions, because they are - that can enrich the way forward (GP1).

The study can also serve as point of departure for future action research, creating the possibility that repeated action research cycles could assist in streamlining relationships between knowledge sharers and enhance the sustainability of service learning partnerships.

\section{REFERENCES}

Albertyn R \& Daniels P. 2009. Research within the context of community engagement. In: E Bitzer (ed). Higher Education in South Africa: A scholarly look behind the scenes. Stellenbosch: SUN PRESS. 409-428.

Alperstein M. 2007. Getting closer to the community voice in curriculum development: An exploration of the possibilities. Education as Change, 11 (3):59-67.

Bender CJG, Daniels P, Lazarus J, Naudé L \& Sattar K. 2006. Service-learning in the curriculum a resource for higher education institutions. Pretoria: Council on Higher Education.

Boyer EL. 1996. The scholarship of engagement. Journal of Public Service and Outreach, 1(1): $11-20$.

Bringle RG, Clayton PH \& Price MF. 2009. Partnerships in service learning and civic engagement. Partnerships: A Journal of Service Learning \& Civic Engagement, 1(1):8-12.

Chapdelaine A, Ruiz A, Warchal J \& Wells C. 2005. Service-Learning Code of Ethics. Bolton, MA: Anker Publishing Company.

Daniels D. 2013. Advancing a transformative learning approach in teacher education through service learning. In: R Osman \& N Petersen (eds). Service Learning in South Africa. Cape Town: Oxford University Press Southern Africa. 186-205. 
Dewey J. 1963. Experience and education. New York: Collier.

Du Plessis C \& Van Dyk A. 2013. Integrating the community voice into service learning: Engaging with communities. In: R Osman \& N Petersen (eds). Service Learning in South Africa. Cape Town: Oxford University Press Southern Africa. 59-84.

Erasmus M. 2007. Supporting academic staff as champions of service learning. Education as Change, $11(3): 109-126$.

Eyler J \& Giles D. 1994. The theoretical roots of service-learning in John Dewey: Toward a theory of service-learning. Michigan Journal of Community Service-Learning, 1 (1):77-78.

Eyler J \& Giles D. 1999. Where's the learning in service-learning? San Francisco: Jossey-Bass.

Furco A. 2001. Advancing service-learning at research universities. New Directions for Higher Education, 1 14:67-78.

Hall M. 2010. Community engagement in South African higher education. Kagisano, 6:1 -52.

Hlengwa A. 2010. Infusing service-learning in curricula: A theoretical exploration of infusion possibilities. Journal of Education, 48:1-14.

Hughes SJ \& Quinn FM. 2013. Quinn's principles and practice of nurse education. 6th Edition. Hampshire: Cengage Learning.

Jordaan M. 2013. A blended approach to service learning: The Faculty of Engineering, Built Environment and Information Technology at the University of Pretoria. In: R Osman \& N Petersen (eds). Service Learning in South Africa. Cape Town: Oxford University Press Southern Africa. 206-229.

Knowles M. 1990. The adult learner: A neglected species. 4th Edition. Houston: Gulf Publishing.

Marjan L \& Peyman S. 2012. Lifelong learning: Why do we need to do it? Social and Behavioural Sciences, 31:399-403.

McMillan J. 2013. 'Service learning' or 'learning service'? In: R Osman \& N Petersen (eds). Service Learning in South Africa. Cape Town: Oxford University Press Southern Africa. 33-58.

Merriam SB \& Caffarella RS. 1999. Learning in adulthood: A comprehensive guide. 2nd Edition. San Francisco: Jossey-Bass.

Mertens DM. 2010. Research and evaluation in education and psychology: Integrating diversity with quantitative, qualitative, and mixed methods. 3rd Edition. California: Sage.

Narayanan NC. 2010. Defining the role of champions in business excellence. [Retrieved 8 April 2014] http://www.processexcellencenetwork.com/lean-six-sigma-businesstransformation/articles/defining-the-role-of-champions-in-business-excelle/

Nduna NJ. 2007. The community voice on service-learning: A good practice guide for higher education. Education as Change, 11 (3):69-78.

Nwokah EE \& Leafblad S. 2013. Service learning to promote brain-based learning in undergraduate teaching. Journal on Excellence in College Teaching, 24(3):69-98.

Piaget J \& Inhelder B. 1969. The psychology of the child. New York: Basic Books. 
RSA DHET (Republic of South Africa. Department of Higher Education and Training). 2014. White Paper for Post-School Education and Training. Pretoria: DHET. [Retrieved 8 April 2014] http://www.che.ac.za/media_and_publications/legislation/white-paper-post-schooleducation-and-training

RSA DoE (Republic of South Africa. Department of Education. 1997. Education White Paper 3: A programme for higher education transformation. Pretoria: RSA DoE.

Shumer R. 2000. Science as storytelling: How should we conduct and report service-learning research. Michigan Journal of Community Service Learning (Special Issue), Fall:79-83.

Skinner BF. 1971. Beyond freedom and dignity. New York: Alfred Knopf.

Stanton TK \& Erasmus M. 2013. Inside out, outside in: A comparative analysis of servicelearning's development in the United States and South Africa. Journal of Higher Education Outreach and Engagement, 17(1):63-96.

Tempone I \& Martin E. 2000. Theory to practice/generic skills/lifelong learning: The connection. Paper presented at the CEET National Conference, 30 October. [Retrieved 22 March 2014] http://www.education.monash.edu.au/centres/ceet/docs/conferencepap ers/2000confpapertempone.pdf

Tsui L, Chapman SA, Schnirer L \& Stewart S. 2006. A handbook on knowledge sharing: Strategies and recommendations for researchers, policymakers, and service providers. Alberta: Community-University Partnership for the Study of Children, Youth and Families.

UFS (University of the Free State). 2006. Community Service Policy. [Retrieved 8 March 2014] http://www.supportservices.ufs.ac.za/dl/userfiles/Documents/00000/357_eng.pdf

Vygotsky L. 1978. Mind in society. Cambridge, MA: Harvard University Press. 


\section{INDEX}

A

abundance $26,115,119-121,126-127$, $132-133,138-139$

academic

academic $23,25,27-29,54,63,67$, 72-73, 77, 83, 85, 89, 107-108, $111-113,116,135-136,138$, $165-166,177,198,224-225$, $236,238,254,258-259,271-272$, 277-278, 286, 288, 291-296, 299-300, 302-303, 307, 309

academic content 294, 302

academic 'contestations' 108

academic curriculum 29

academic disciplines 136

academic expertise 165

academic knowledge 23, 29, 299-300, 307

academic life 63, 108

academic programmes 25, 54, 165, 224

academic research 67, 254, 303

academics $28,33,66-67,69,72,80$, $84,90-91,106-107,112,116$, $138,164,170,254-255,271,291$, $294-295,300,302$

academic SL 292

academic staff 116, 258, 271-272, 278, $286,288,303,309$

academic student service placement 23, 198

accountability $22,70,80,82,85-86$, $91-92,96-98,115,156,166,195$, $200,205,207,210-211,213,221$

Act

Biodiversity Act 10 of 2004 88, 98

Constitution of the Republic of South Africa, Act no 108 of 1996 197, 213

Higher Education Act 101 of 1997 165, 177,213
Income Tax Act 58 of 1962184

National Environmental Management 88, 98

National Environmental Management Act 107 of 199888,98

New Companies Act 71 of 2008 183, 193

Nonprofit Organisations Act 71 of 1997 $27,36,122,141,194$

action research $24,36,87-88,170,278$, 308

activism

activism 24, 267

activist $62,66-67,74,77,89,108,254$

activist research $62,66-67,77$

activist scholars 74

African context 21-22, 25, 27, 60, 73, $102,106,109,111,122,130$, $168,170,198,206,221,291$

African university $35,41,108,117,141$

agency $32-34,43-45,48,77,97$, 120-122, 124-126, 129-133, 136, $138-140,161,177,252,289$

agents of change 45, 108, 134, 250

assessment 130, 257-258, 264-265, 267, 288

assets $43,46,57,75,77,125,132,140$, 165

attitude 30, 33, 48, 164, 206, 296, 299

authentic dialogue $32,195-198,205$, 210-211

\section{B}

Batho Pele principles 195-197, 199-200, 204, 207, 211

beneficiaries 84-86, 89, 147, 149, $152-155,157-158,162-163,171$, $185,187,192,221,245$ 


\section{KNOWLEDGE AS ENABLEMENT}

Blackboard 270, 272, 278

boundary

boundaries 29, 32, 34-35, 69, 73, 89, $116,133,173,196$

boundary $29,32,36,62,67,73-78$, $166,168,177,224-225$

boundary (knowledge) worker 29

boundary spanners 75

boundary spanning 62, 67, 73-75, 77, $166,168,177$

boundary spanning actor 74

boundary spanning role 74-75

boundary work 32,36

Boyer 21, 34, 64, 66, 76, 291, 308

brain-based research 298

Bringle 23, 36, 48, 53, 60, 73, 78, 106, $118,176-177,198,213,221$, 234, 255, 268, 271-273, 279, 281-282, 288-289, 301, 308

Butin 24, 34, 43, 46, 56-57, 60, 112-113, $115-116$

C

capacity building 23, 168, 198, 201, 210-211, 239, 305

champions $30,116,290,292-300$, 302-309

change

change 24, 28-31, 33-34, 36, 41, 43, $45,53-56,59-60,64,67,69,72$, $77,79,82,86-90,96-97,101$, $104,106,108,110-111,115-116$, $120,126-127,133-135,138-139$, 154-155, 159, 163, 166-168, 177, $188,195,204,206-207,211$, $213,242,250,266-267,290-293$, 296-300, 302-303, 305, 307-309

change agents 56, 293, 297-298, 302-303, 305

observable change 55

occupational changes 56

positive change 43,67

transformational change 59, 120 choice $41,44,46-47,49,59,84-85,112$, $130,157,174$

Chomsky 101, 115-116

citizen participation 199, 201, 205

citizenship 35, 45, 77, 96, 108, 110-111, $117,235,263,267,297$

civic engagement 60, 221, 234, 255, 266, $273,288,308$

civic responsibility 43, 224, 270

civil society $23,25-26,79,81-82,85$, $97-98,100,102,108,116,123$, $135,146,155,160,164,181$, 193-196, 198-200, 212-213, 254, 291

client participation 41, 44, 52

collaboration 22-25, 27, 29-30, 32 , 45-47, 49, 63, 65-66, 70, 73-74, $82,89,109,120,133,135-137$, $156,158,172-173,179,192$, $196,198,210,217,219-221$, 225-229, 233, 235, 246, 250, 254, 258, 269-273, 277, 279, $281,288,300-301,303,305,308$

collaborative

a collaborative $32,48,62,72,111,138$, $254,270,278,281,298$

collaborative 22-24, 32, 42-44, 47-48, $59,62-63,65,72-73,77,81,87$, $103,110-111,115-116,132,138$, $156,158-159,170,172,197,205$, $227,254,266,269-272,278,281$, $287,291,298$

collaborative action 116

collaborative activities 44, 271

collaborative decision making 47-48, 59

collaborative engagements 266

collaborative investigation 42

collaborative knowledge-building 23

collaborative knowledge construction 110

collaborative learning experience 254

collaborative partnerships 63, 156, 158-159, 170

collaborative platform 62

collaborative relationship 132, 205 
collaborative relationships 172, 197

collaborative space 269-270, 272, 278, $281,287,291$

collaborative work 32, 278

\section{communication}

barriers to communication 49

clarity of communication 259, 264

clear communication 48-49, 51, 262, 264

communication 30, 45, 48-52, 59, 81 , $156,159,161,165,194,196,204$, $208,210,225,239,249,251$, 253, 259-262, 264, 266, 269-273, 275-289, 299, 301, 305

communication gap 51, 210

communication skills 262

continuous communication 48, 305

experiential communication 276

face-to-face communication 51-52

formal communication 301

formalised communication structure 51

frequent communication 51

honest communication 45, 50-51, 59

increased communication 279

lack of communication 259

mutual communication platform 270-272, 275-287

one-way communication 204

online communication 269-271, 287-288

open channel of communication 210

proper communication 273, 287-288

\section{community}

communities 23-25, 27-31, 33-34, $37,41-47,54,57,59-60,62-66$, 69-72, 74-77, 80-90, 92, 96-97, $102,106,113,115,120-121$, 123-128, 130-139, 145-146, 148, $157,159,164,167-174,177,179$, 188-189, 191, 200, 212, 218-219, $221,224,230,233,237,239,244$, 246, 254-256, 267, 277, 289, 291, 293-294, 309 community $21-26,28-30,32-37$, $41-67,70-78,81,83-84,86-91$, 96-97, 99-113, 115-118, $121-124$, 126-128, 131, 133-138, 140-141, $145-146,148,153-155,157,159$, 162-165, 167-174, 176-178, 180, 187-188, 191-192, 195, 198, 202, 205, $211-213,217-219,221-225$, 229, 233-235, 238-239, 241-242, $244,246,250,254-255,267-271$, $275,278,280-281,287,289-310$

community-based research 29, 33, 65,

$78,90,92,96,111,118,271,289$

community constituencies 87

community development 43, 60-61, $73,97,118,140,159,234-235$, 302-303

community education 29

community-engaged scholarship (CES) 29, $33,62-77$

community engagement $21-25,28-30$, $32-36,41-43,45-46,56,60,63$, 70, 73, 77-78, 81, 83-84, 87, 89, 96, 100-113, $115-118,133-136$, $140-141,162,164-165,172,180$, $213,217,219,221,224,229,235$, 241-242, 250, 254-255, 267-268, 270-271, 290-291, 293-294, 302-303, 308-309

community engagement imperative 21 , 105

Community - Higher Education - Service Partnerships (CHESP) 42, 73, 77, 110, $112,115-116,140$

community interaction 21, 66

community participation 44-45, 48, $50-51,59,270$

community representatives $41,46-47$, $49-50,52,57-58,301$

community service $37,46,60,101-102$, $105,108,116-117,172,177,267$, $289,291,294,310$

community voice $34,36,60,112$, $211-213,293,308-309$

university-community collaboration 66 university-community interaction 66 university-community links 72 


\section{KNOWLEDGE AS ENABLEMENT}

university-community partnerships 173, 234

university-community relations 62

compassion 124,153

compassionate imagining 29, 37

confidence $29,45,49,52-53,59,125$, $171,173-174,274$

connectedness 217

constituencies $31,82,86-87,102-103$, $105,113,273$

constructive change 34

constructivist 46, 66, 277, 290, 294, 297

contradiction 109

co-production $62,67,74,78,88,254$, $256,260,307$

Corporate Social Investment (CSI) 130, 240

Corporate Social Responsibility (CSR) 240, 246

Council on Higher Education (CHE) 60, 77, 105-106, 116-118, 140, 308, 310

creativity $30,32-33,35,264$

curriculum 29, 34-36, 60, 110, 211, 308

D

democracy 101, 110-112, 167, 212

democratic

democratic 37, 77, 83, 100-101, 105-106, 109, $111-112,199,213$, 255-256, 290, 292, 297, 301, 303, 308

democratic participation 112

democratic values 213

Department

Department 36, 46, 58, 61, 63, 78, $98,102,106-107,117-118,124$, $141,161,178,180-181,183-184$, 187-194, 202, 213, 218, 225, 235, $239,245,251,280,310$

Department of Economic Development, Tourism and Environmental Affairs (DETEA) 192, 243
Department of Education (DoE) 101, 106 $108,118,165,178,202,218,224$, 235,310

Department of Health (DoH) 124

Department of Higher Education and Training (DHET) 22-24, 36, 42-43, $61,63-64,78,81,98,101-102$, $107,117-118,303,310$

Department of Social Development (DoSD) $36,122,141,180-184,187-194$, 202,245

\section{development}

collaborative development 65

community development 43, 60-61, 73, 97, 118, 140, 159, 234-235, 302-303

development 25, 27-28, 30-32, 34-36, $43,51,55,60-61,65,67,70$, $72-74,76,79,81,83,86,96-99$, 105, 108-109, $111-112,118,120$, $126,128,130-131,134,139-141$, 154-155, 157, 159-161, 165, 170, 172-173, 177, 179-181, 183-184, 186-194, 197, 200, 202, 210-211, 213, 226, 229, 231-232, 234-235, 237-238, 241-246, 250-258, 260-266, 268-269, 271, 274, 277, $279,284,287-288,290-292$, 298-304, 307-308, 310

development aid 126

development research 170, 255, 257, 260-263, 266

development studies 183

economic development 130, 134, 161, $172,192,200,243$

individual development 111,303

leadership development 159, 165

people-centred development 27

personal development 226, 231-232

professional development 229, 264, 307

self-development 296-297, 299

social development 36, 141, 180-181, 183-184, 187-191, 193-194, 202, 243, 245, 255, 299-300

social enterprise development 244, 246, 252 
sustainable development 70, 128, 197

youth development 177

Dewey 60, 111, 117, 267, 297, 309

dialogue 22, 32, 43, 59, 61, 66, 104, 132, $134,138,145,171,195-198$, 205, 207, 210-211, 249, 266, $278,291,303$

dignity 122, 124, 152-153, 157, 167 , $170,206,310$

discipline 55, 60, 63, 70-71

disciplines 70, 81, 126, 129, 131-132, 136,212

E

economic development 130, 134, 161, $172,192,200,243$

education

community education 29

education 21-31, 33-37, 41-42, 46, 54, 59-61, 63, 68-69, 73-74, 76-81, 84-85, 91-92, 96-98, 100-103, 105-113, 115-120, 125, 132-134, $137,139-141,145,147,152$, 158-159, 161-165, 169, 171-173, 176-181, 192-193, 196, 198-199, $202,210-213,217-219,221$, 224-225, 234-236, 238, 241, 243, 249-250, 252, 254-256, 263, 267-268, 270-272, 275, 287-296, $300,302-310$

education transformation 100, 102, 105, $112,118,178,310$

post-school education 23-24, 27, 36, $61,63,78,81,98,101-102,107$, $117-118,303,310$

student education 54, 111

empowerment 29, 43, 82, 85-86, $96-97,121,193,197,298,300$, 302-303, 305, 308

enable $26,28,43,49,63,65,70,74,80$, $82,91,96,115,119,155-156$, $159,165,173,197,217-218$, $220,245,271,276-277,279$, $291,299,302-303,308$

\section{enablement}

enablement $21-23,25,28-31,33-34$, $41-60,62,64,100,103,110,163$, 165-166, 179, 181, 193, 197-198, 236, 238, 242, 247, 249-250, 253, 266, 290, 292, 298-300, 305, 307

enablement foundations $41-44,47-48$, $50,52,58$

knowledge enablement 21, 23, 28, 31, $33,62,64,100,163,179,181$, $193,236,238,242,249-250,253$, 266

\section{engagement}

civic engagement 60, 221, 234, 255, 266, 273, 288, 308

community engagement $21-25,28-30$, 32-36, $41-43,45-46,56,60,63$, 70, 73, 77-78, 81, 83-84, 87, 89, $96,100-113,115-118,133-136$, 140-141, 162, 164-165, 172, 180, $213,217,219,221,224,229,235$, 241-242, 250, 254-255, 267-268, 270-271, 290-291, 293-294, 302-303, 308-309

constructive engagement 25, 179, 192 engagement 21-37, $41-46,48-51$, $53,55-56,60,63-65,67,70-73$, 76-78, 80-81, 83-85, 87-89, $92,96,98,100-113,115-120$, 125-126, 131-137, 140-141, 162, 164-165, 169, 172-173, 179-181, 192, 198-199, 210-211, 213, 217, 219, 221-222, 224, 229, 233-235, $241-242,250,254-256,259,262$, 265-268, 270-271, 273, 278, 288-295, 301-305, 307-310

enterprise $24,26,36,66,71,111$, 119-120, 130, 179, 192, 237, 239-242, 244-247, 251-252

equality $26,57,59,121-122,129,255$, 302

equity $21,48,50,129,153,176-177$, 281-283, 286, 301

ethical 30, 36, 66, 70-71, 80, 82-92, $96-97,104,107,148,160,166$, $174,213,262,267,277,288$, 294-295 


\section{KNOWLEDGE AS ENABLEMENT}

ethical considerations $30,83,85,88,92$, 96

ethical dilemmas $80,83,85,87,89-90$, 97,213

ethical engagement $80,89,92$

ethics $26,29-30,34,78,80,83-85$, $89-92,96,99,141,159,176$, 295,308

ethics frameworks 96

exclusion 50, 67

experiential learning (EL) 23, 31, 35, 76, 253-254, 256-257, 262, 265, 293, 297-298, 308

F

facilitation 31, 74, 165-166

faith-based organisations $26,122,137$, $145,147-148,151,153,156$, 160-161

fieldtrip 253-254, 256-267

focus group discussion (FGD) 195, 197, 201-203

Freire 29

G

gatekeeper 259

gatekeepers 108, 169, 171

Gibbons 22, 35, 68-69, 71-72, 77, 105, $107-108,116,133,140$

Global Entrepreneurship Monitor (GEM) 240

globalisation 186

governance $77,82,85,134,145$, $155-161,164-165,173,179,181$, $185,187,193,196,199-200$, $204,210-213,243,245,252$

government $26-27,36,63,74,86-87$, $98,102,106-107,109-110,112$, $118,123,130,140,154,170$, 178-181, 186-191, 193-197, 199-202, 204-213, 236, 239, 241, 244-246, 251, 254
$\mathrm{H}$

Hatcher 42, 60, 110-111, 117, 176-177, 273,288

higher education

higher education 21-28, 30-31, 33-37, $41-42,46,58-61,63,68-69$, 73-74, 76-81, 84-85, 91-92, 96-98, 100-103, 105-113, 115-120, 132-134, 137, 140-141, 145, 147, $152,158,162-163,165,169$, $171-172,176-181,192-193,196$, 198-199, 210-211, 213, 217-219, $221,224,234-236,238,241$, 249-250, 252, 254, 267-268, 270-271, 287-292, 294-296, 302-310

higher education community engagement $33,100,102-103,113,118,221$

higher education context 21, 102

higher education engagement 21, 108

higher education institution (HEI) 23, 28, $43,48-50,56-57,74,111,151$, $159,165,168-169,171-174,181$, 192-193, 219, 222, 224-233, 238, 294

higher education institutions (HEIs) $21-23,25-28,41-42,46,54,60$, $63,69,73-74,80-87,89,91-92$, $96,102-103,105-107,109-110$ $119-120,125-126,129-133,147$, 151-152, 156, 158-159, 162-166, 169-172, 174, 176, 180, 192, 196, 198-199, 217-219, 221-222, 224, $234,238,241-242,247,249-250$, 270, 287, 291, 296, 299, 302-303, 305, 307-308

higher education leaders 171

higher education management skills 147 , 158

higher education partnership 165, 169

higher education sector 24-25, 106-107, $113,115,180,198,290-292$, 294-295, 302, 308

higher education staff members 270-271

higher education system 23

higher education transformation 100, 102, $105,112,118,178,310$ 
I

ideological 24, 100, 102-105, 113, 115, 255

ideology 100, 104, 113, 116, 155, 245

impact $29,53,55,97,100,107,125$, $129-133,135,147,150,153$, $155,160,170,221,234,241$, $254,268,277,295,301$

inclusion 50, 57, 59, 69, 172, 202, 278, 294

income-generating 179, 181, 191-192, 239, 243-245

Industrial Finance Corporation (IFC) 241

inequality 43, 46, 63, 81, 103, 121

information exchange $33,274,276$

innovation 22, 24, 26, 28, 30, 34-36, 65, $71,77,119-121,127,130,133$, $137-138,140,154,159,239$, 242,251

institutional $32,35,51,65,73,80,83-84$, $89-90,97,101,118,120,160$, $168,171-172,187,200,235,240$

institutional ethics committees 80

institutionalisation 171

interact 25, 29, 69, 102, 106, 164, 179-180, 195, 275-276

interaction 21, 28-30, 32, 48, 53-54, $59,66,100,103,135,176,206$, 217-222, 224-225, 227, 229-230, $233,262,271,273,275-276,281$

interactions $24,30,32,46,89,164,176$, 221,275

interest groups 23, 138, 151

international fieldtrip 253

International Labour Organization (ILO) 179, 181, 192, 237, 239, 241-242, 250-251

International Society for Third-Sector Research (ISTR) 36, 123, 140, 213

interorganisational networks 217-219, 222,234

ivory tower 66,107
J

Jameson 100, 102-105, 108-109, 113 , 115-118

justice

environmental justice 122, 131

injustice 67, 200, 290, 300

justice 21 , 35, 37, 41, 43, 45, 50, 56, $59,61,64,77,89,96,111,115$,

$117,122,124,127,131,138-139$,

$196,235,254,267,300,305$

social justice $21,35,43,45,56,77,89$, $96,111,115,117,127,138,235$, $254,267,300,305$

K

knowledge

common knowledge 28, 34

co-production of knowledge 74, 260, 307

indigenous knowledge 74, 135, 164

indigenous knowledges 91

interactive knowledge production 67

knowledge 21-25, 27-37, 41-42, $45-46,48,56-60,62-85,88,90$, $92,96,98,100,103,105-111$, $116,119-120,125,130-138,141$ $145,147-148,151-152,154-156$, 158-159, 163-165, 168-169, $171-173,176,179-181,191-193$, 197-198, 202, 210, 217-221, 223, 225-226, 229-233, 236, 238-239, 241-242, 249-250, 253-256, 258, $260,264,266,269-272,274-279$, $281-284,287-308,310$

knowledge brokers 28-29, 223

knowledge construction 110,274, 276, 283

knowledge creation 21, 24, 33, 103, 173

knowledge economy $25,67,73,76,107$, 109

knowledge enablement $21,23,28,31$, $33,62,64,100,163,179,181$, $193,236,238,242,249-250,253$, 266 


\section{KNOWLEDGE AS ENABLEMENT}

knowledge generation 46, 63, 67-68, $107,134,138$

knowledge interactions 30

knowledge partners 21

knowledge production 22, 33, 67-70, $74-75,77,81,83,90,132,256$

knowledge sharing $22,25,30,41$, 58-60, 63-64, 66, 80-82, 84-85, $92,96,111,198,210,219,223$, 226, 229-233, 269-272, 277, 279, 281-282, 287-288, 290-293, 295, 297-308, 310

knowledge sharing network 230, 232, 306

local knowledge 131

local knowledges 134-135

Mode 1 knowledge 69

Mode 2 knowledge 35, 69, 107-108, 133

L

leadership

leadership 35, 65, 97, 125, 134 137-138, 140-141, 159, 161-162, 164-168, 176-177, 212, 258, 282-283

transformational leadership 162, 166, 176

\section{learning}

academic learning 291, 302

accelerated learning 260

active learning 276

adult learning 297-298

co-learning 254

collaborative learning 254

experiential learning (EL) 293

learning 23, 25, 29-37, $41-42,45-46$, 58-61, 65, 69, 73, 77, 81, 101-102, 104-106, 108, 110-113, 116-118, $131-132,134-135,137-138,140$, $152,158-159,161-165,168-172$, $177,180,212-213,221,224-225$ 229, 234, $241-242,253-262$, 264-271, 274, 276-279, 281-282, 284, 287-291, 293-295, 297-299, $302-303,305,307-310$ learning city 134

learning community 278, 290, 303, 307

learning environment 299

learning management system 30, 271, 276

learning outcomes 224, 253, 256, 258, 266

lifelong learning 35, 140, 282, 297, 299, 309-310

local community learning hubs 137

online learning 274, 279

optimal learning 135

professional learning 278

reciprocal learning 255, 264, 266

relational learning 298, 305

student learning 110, 262, 267

teaching and learning $110,135,168$, 224, 241-242, 257, 281, 289, 291

teaching-learning 105

'whole brain' learning 298

legitimacy 64, 81-82, 84-86, 88, 249

local neighbourhoods 26, 119-120, $131-134,136$

$M$

management skills 27, 145, 147, 151, 158-160, 187

mediation 31,33

Mode 1 knowledge production 69

Mode 2 knowledge production 69

Mode 2 research 69

Mode 2 Society 77, 116, 140

Mode 2 Society 107, 116

mutuality 49, 121, 130-131, 133, 135, $139,256,289,305$

N

National Research Foundation (NRF) 106

NetDraw 226, 234 
network

collaboration network 226-227, 229, 233

knowledge sharing network 230, 232, 306

network 28, 139, 141, 174, 177, 183,

$187,208,217-230,232-235,243$

$275,301,305-307$

organisational network 221

non-profit organisation (NPO) 21-24

26-28, 33, 42, 46, 55, 120,

$122-123,127,137,145-150$,

$152-160,162-166,168-172$,

179-198, 202-204, 207-211,

219-220, 222, 224-232, 236-247,

250-266, 269-272, 276-288, 291, 293-295

non-profit sector 26-27, 35-36, 117 ,

$161-162,179-180,183,186-187$, 193-194, 244-245

nursing education 224-225, 293-294

Nyerere 60, 111, 117

O

occupational therapy (OT) 41-44, 46-47, $49,55-56,58,60-61$

online learning model 274

organisational culture 195, 206, 211

Organization for Economic Cooperation and Development (OECD) 237, 252

$\mathbf{P}$

paradigm

constructivist paradigm 46, 290, 294, 297

paradigm $46,62,66,83,126,133,141$, 290, 294, 297

participation $25,29-31,41,44-45,48$ $50-52,59,77,80-82,85-86$, $90-91,96-97,110,112,135,169$, $172,181,196-197,199,201-203$, 205, 210, 212-213, 250, 255-258, 261-262, 270, 275, 307

participatory action research (PAR) 24, 86-88, 98, 105

participatory knowledge sharing 30 , $80-82,85,96$ participatory research $36,80-81,83-85$, 87-90, 96-97

\section{partnership}

close partnership 136

collaborative partnerships 63,156 , $158-159,170$

community partnerships 173, 224, 233-235, 270

contract-based partnerships 156

development partnerships 108

equal partnerships 136

formal partnerships 156

fully-fledged partnership 168

HE partnership 24

inclusive partnerships 112

informal partnerships 152, 156

knowledge-generating partnerships 63

knowledge partnership 22

long-term partnerships 84

multistakeholder partnerships 82, 87

mutually beneficial partnership 65

mutually enabling partnership 44

optimal partnerships 26, 119

organisational partnerships 221

partnership 22, 24, 27-28, 33, 44-45, 48-55, 57-60, 65, 73, 76, 80, 83-85, $87-90,92,96-97,112,125-126$, $131,133-134,136,138,147,156$, $158,162-163,165-166,168-174$, $177,181,189,192,196,198,204$ 208, 210, 213, 218, 221, 229, 234, 246, 281, 291-293, 295-296, 298, $300-301,304,310$

Partnership agreements 80, 83-85, 96 partnership building 73, 204, 218, 221

partnership climate 291

partnership context 281, 292-293, 295, 300,304

partnership development 300

partnership dynamics 28

partnership ethics 92

partnership formation 50 


\section{KNOWLEDGE AS ENABLEMENT}

partnerships 22-23, 25-26, 30-31, 35, $41-42,45-46,50-51,55,57-60,63$ 73-78, 80-92, 96-97, 99, 108, 110, $112,116,119,125,129-130,133$ $136,140,145,152,156,158-159$, 162-163, 170-171, 173-174,

176-177, 180-181, 201, 208,

$217-218,221,224,229,233-235$ 249, 270, 288, 290-292, 294-296, $298,300-301,308$

partnership triad model 112

productive partnerships 133

quality partnership 229

reciprocal partnership 147

reciprocal partnerships 145, 180

service learning partnership 59

SL partnership 44-45, 48, 52, 55, 57-58, 292-293, 300

SL partnerships 45-46, 55, 57-58, 291, 300-301

smart partnerships 233

sound partnerships 201, 208

strong partnerships 129

sustainable partnerships 73, 300

symbiotic partnership 298

the partnership 33, 44-45, 48-52, 54, 57-60, 87-88, 162-163, 170-172, $181,281,300-301$

triad partnership 112, 293

well-functioning partnerships 234

pedagogy of possibility $24,62,64,71-72$

perceptions 41, 46-47, 49, 52-53, 56-58, $61,166,168,170,201,207,221$, $276,290,292,294,306-307$

policy $24,26,30,33,37,65,78,81,83$, $87,90,92,98-101,106,110$, $130,181,192-194,200,204$, $211,220,234-235,238-239,242$, 250, 257-258, 264-265, 267, 289, $294,303,310$

policy directives 33, 100-101, 110

Political Unconscious 24, 100, 102-104, $113,116-118$ possibilities

age of possibilities 71

possibilities 34, 41, 45, 52, 55, 59-60,

71-72, 78, 102, 107, 211,247 ,

249-250, 254, 261, 290, 308-309

Utopian possibilities 102

vision of possibilities 41, 45, 52, 55, 59

postcolonial 136, 254-256, 259, 266

postgraduate $35,224,266$

power

devolution of power 43

power 23-25, 28, 32-33, 41, 43, 46, 51, 56-60, 81-83, 87, 89, 91, 97-98, 104, 106-107, 109, 120-122, 138-139, 146, 154, 161, 166, 168-170, 173, 201, 207, 223, 227 , 233, 246, 255, 260, 263, 270, 302

power sharing $41,46,56-57,59$

practice $24,26,29-31,33-34,36-37$, $46,60-61,65,68,71-72,74$, $77,96,112,115-116,118,121$, $134,139,153,161,176,213$, 234-235, 246, 251, 254-259, 262-263, 267, 278, 289, 294-297, 299-300, 306, 308-310

Preece 108, 117, 132-133, 135, 141, 275-276, 289

professional

professional 34, 55, 174, 229, 259, 264, 278, 293, 307

professional development 229, 264, 307

professional learning community 278

professional nurses 293

professional practice 259

professional responsibility 174

professionals 32, 55, 59, 61, 109, 181, 186

\section{programme}

academic programme 23, 107

academic programmes 25, 54, 165, 224

community engagement programmes 107 , 134 
empowerment programmes 86, 193

learning programme 117, 159, 265

learning programmes 25,81

programme $23,27,47,54,56,61,81$

$106-107,117-118,140,159,178$,

$194,235,265,310$

programme planning 81

programmes $23,25,27,54,81,86$, $88-89,98,101,107,127,129,134$, $148,150,155,159,165,172,190$, 193, 209-210, 224, 242, 245, 296

service learning programme 117, 265

Public Good 66, 78, 102, 108, 117-118

public service delivery 197-201, 206-208, 210,212

Q

quality

quality $77,82,98-99,110,116,118$ $129,140,171,175-176,196,204$, $229,235,251,281,298,300-301$, 304-305

quality assurance 110,300

quality indicators 300-301

quality knowledge sharing 304-305

quality partnerships 235

R

reciprocal

reciprocal 22, 24-25, 30-31, 41, 43, $50,57-60,63-64,66,70,110-111$, $119-120,132-133,145,147$, 162-163, 165, 168, 180, 197-198, $210,236,247,250,253-256,264$, $266,270,281-282,290,292-293$, 298, 300-302, 305, 308

reciprocal benefits 31

reciprocal knowledge sharing 22, 25, 30, $41,58-60,63-64,66,111,198$,

$210,290,292-293$

reciprocal learning 255, 264, 266

reciprocal relations 162-163, 165, 253-254 reciprocity $28,30,32,49-50,58-59$, $133,135,139,165,171-172,176$, $250,256,258,286,305$

reflection $23,65,68,132,134,137-138$, $163,192,263,297,301,305$

reflections $85,97,104,163,212,253$, 255-256, 258, 261, 266-267, 286

reflective journal 279, 282, 284-285

reimagining $24,75,115,119-121,132$, 137

relational dimension of change 31

relationships $29,31,33,47,49,51$, 53-54, 65-66, 73, 89, 96, $120-121,133,165,167-169$, 172-174, 176-177, 187, 197, 210, 218-219, 221, 244, 246-247, 249-250, 271-273, 275, 288-289, 301,308

relevance $30,55,67,70-71,133,135$, $171,246,252,267,291,302$

religious faith $27,145-160$

research $21,23-30,32-37,46,55-56$, $60-72,74,76-78,80-85,87-92$, 96-97, 99, 101, 105-107, $109-111,116,118,123,132$, $134,136-138,140,147-149,158$, $160-161,170-171,174,176$, $179-181,183,186-187,192-195$, $198,201,210-213,219-220$, 224-225, 234-235, 237-238, 241-244, 246, 249-267, 270-271, 278, 288-292, 294-295, 298, $302-303,308-310$

resistance 31,116

resource

resource $23,27,60,81,84,138,211$, $219,224,233-235,257,308$

resource allocation 224

resource gap 81

resource-poor people 121

resource requirements 84

resource-rich actors 233

resource-rich people 121-122

under-resourced 109 


\section{KNOWLEDGE AS ENABLEMENT}

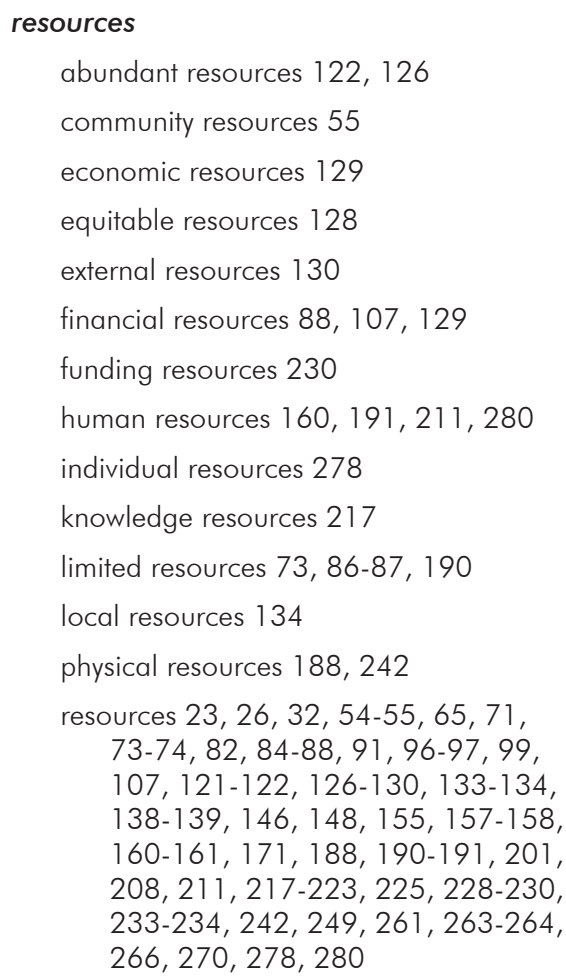

scarce resources 220

self-generated resources 121

table of resources 139

respect $26,45,57-59,65,122,152-153$, $164,166,199,241,271,275$, $300,302-303$

responsibility

civic responsibility 43, 224, 270

professional responsibility 174

responsibility $41,43-45,47,49,52,68$, $70,102,108,111,150,165,172$, $174,218,224,240,244,246,256$, $263,270,296-299,301,305$

social responsibility $102,111,172,218$, 240, 246, 256, 299

responsible citizenship 45, 110-111

reward 47-48, 127, 298

risk 24, 34-35, 41, 44, 47-49, 63, 76, $83-84,88,91,163,172,241,258$
Role clarification 47,49

role players 115,277

\section{S}

Salmon 271-272, 274-280, 282-284, 289

scarcity 119, 121, 126, 129, 139

scholarly community engagement 41-42

scholarship

activist scholarship 66

community-engaged scholarship (CES) 29, $33,62-77$

engaged scholarship 24, 75, 83, 97, 115

mainstream scholarship 69

scholarship 24, 29, 33-34, 62-66, 68-71, $73,75-78,81,83,97,115,133$, $135,163,291,305,307-308$

scholarship of engagement 76, 291, 305, 308

traditional scholarship 69

School of Nursing (SoN) 224-225

sector

sector $21-36,42,62-64,67,73-76$, 78-92, 96-97, 100, 102-103, $106-108,113,115,117-134$, $136-137,139-141,143,145-147$, $150,153,158,160-165,167,169$, $171-174,176,179-181,183-184$, 186-187, 189, 192-201, 207-208, 210-213, 217-224, 229-230, 233-238, 242-247, 249, 254, 266, 290-292, 294-295, 301-305, 307-308

third sector $21-23,25-34,36,42$, 62-64, 67, 73-76, 78-92, 96, 100, $102-103,106,115,119-134$, 136-137, 139-140, 143, 145-147, $153,158,163-165,169,171-174$, $176,179-181,192-201,207-208$, 210-213, 217-224, 229-230, 233-234, 236-238, 247, 249, 290-292, 294-295, 303-305, 307-308

sectoral relationships 244, 246-247

sense of belonging 278 
service $23-25,30-32,34,36-37,41-42$, $45-46,48,54-55,58-61,63,66$, $68,70,73,76-77,98,101-102$, $104-106,108-113,116-118,121$, $125,135,140-141,146,155$, $158,162,164-165,170-174,177$, $179-181,184,188-189,193-201$, 204-213, 221, 224-225, 229, 234, 246, 253-257, 259, 261, 265-270, 276-277, 279-282, 287-291, 294-295, 301-302, 307-310

\section{service learning}

philosophy of service learning 259

service learning academics 294

service learning approaches 255

service learning champion 293, 298-299

service learning champions 30,290 , 292-293, 295-296, 298-300, 302

service learning community 290-294, 296-300, 304-305, 307

service learning context 31, 44, 272, 303 service learning definition 281

service learning engagement 46, 48-51, 53

service learning engagements $41-43$, $46-49,52-60$

service learning experience 49, 272, 277 , $285,287,301$

service learning experiences 294

service learning field 292, 296, 304

service learning ideals 266

service learning initiative 112

service learning module 225, 229, 271, 279, 286, 288

service learning participants 30, 269-273, $281,287-288$

service learning partners 48, 271, 273

service learning partnership 44-45, 48, $52,55,57-59,292-293,300$

service learning partnerships $41,45-46$, $55,57-58,112,291,300-301,308$

service learning pedagogy 256, 301

service learning pioneers 291

service learning practice 296-297, 299-300 service learning practices 261, 307

service learning principles 49

service learning programme 54, 117, 265

service learning projects 135, 162, 170, $269,286-287$

service learning relationships 273

service learning researchers 291

service learning (SL) 30-31, 34, 36, $41-42,45-46,58-61,73,101-102$, 104-106, 108, 110-113, $116-118$, $135,158,162,164-165,170-172$, $177,180,212-213,221,224-225$, $229,234,253-257,259,261$ 265-270, 276-277, 279, 281-282, 287-291, 295, 307-310

service learning stakeholders 51, 307

service learning style 266

SL 42-60, 118, 270-273, 278-279, 281, 285-286, 291-305, 307

South African service learning 31, 112

sharing $22,25,30,41,46,56-60,63-66$, $80-82,84-85,92,96,111,122$, $127,133,139,145,148,168$, $173,176,197-198,210,219$, 223, 226, 229-233, 245-246, 255, 266, 269-272, 277-279, 281-282, 287-288, 290-293, 295, 297-308, 310

social enterprise $36,179,237,239-242$, 244-247, 251-252

social entrepreneur 237

social entrepreneurship 27, 127, 141 , $193,236-242,245,247,249-252$

social justice $21,35,43,45,56,77,89$, $96,111,115,117,127,138,235$, $254,267,300,305$

socially symbolic act 103-104, 107, 117

socially symbolic acts 102, 104, 110, 113, 115

social networks

social network analysis (SNA) 28, 217-221, 223-226, 229, 234-235

social networks 217, 219, 223, 230, 234-235, 270

social responsiveness $24,56,70$ 


\section{KNOWLEDGE AS ENABLEMENT}

social transformation $43,73,110,135$, $165-166,255,297,299,303,307$

solidarity 86, 122-124, 222, 239

South Africa 21-22, 25-26, 32, 34-37, $49,59-61,73-74,78,84,88$ 90, 98-102, 105-106, 108-113, $116-118,121,123-124,141,146$, $161,177-181,183,185,192-194$, 196-197, 199-200, 207, 212-213, 217-219, 235, 237-241, 251-254, 256-257, 267-268, 289, 292, 308-310

South African Higher Education Community Engagement Forum (SAHECEF) 102, 118

Stanton 110, 112, 118, 255, 264, 268 291,310

student

Fulbright student 174

nursing education students 224, 294

OT students 46

service learning students 259

student 23, 35, 46-48, 53-55, 58-59, 69, $110-111,174,198,212,255-256$, 258-259, 261-264, 266-267, $278-279,281,283$

student activities 55

student assessment 264

student competence 48

student expectations 261

student group 258, 263

student involvement 53, 55

student learning 110,262, 267

student outcomes 46

student perspective 281

student preparedness 48

student presence 53, 59

student questionnaire 278, 281

student reflections 255

student researchers 262 students $23,25,28,34,43,46-50$, 52-58, 73-74, 108-112, 117 , $135-138,158,161,165,167$, 169-172, 176, 224, 253-267, 269-272, 274-286, 288, 291, 294-295, 299, 302-303

student service 23, 55, 198

sustainability 24, 26-27, 30-31, 53-54, $59,78,82,115,119-121$, $127-131,133,138-139,145-147$, $152,154,158,161,172,180$, 187-189, 192-194, 208, 236-239, $251,270,298,300,303,306,308$

T

Tangible products 53-54, 59

teaching and learning $110,135,168$, $224,241-242,257,281,289,291$

teaching-learning 105

technology $30,68,75,140,159,161$, $258,275,277,288,309$

theory and practice $34,46,60,68,96$, $116,118,297,299,308$

third sector

higher education-third sector engagement $21,25,198$

International Society for Third-Sector Research (ISTR) 36, 123, 140, 213

third sector $21-23,25-34,36,42$, 62-64, 67, 73-76, 78-92, 96, 100, 102-103, 106, 115, 119-134, 136-137, 139-140, 143, 145-147, $153,158,163-165,169,171-174$, $176,179-181,192-201,207-208$, 210-213, 217-224, 229-230, 233-234, 236-238, 247, 249, 290-292, 294-295, 303-305, 307-308

third sector actors 218,238

third sector consciousness 121

third sector engagement 21, 25, 106, 198

third sector ethics 85,92

third sector network 221 
third sector organisations 22-23, 26, 67, 73-74, 82, 84-88, 92, 120, 122, $124-127,129-134,136-137,139$, $145,196,198,217-220,222-224$, 230,234

third sector participants 23

third sector partners 80, 88, 222

third sector praxis 131-132

third sector research 25, 34, 36, 76, 194 , 212

third sector sites 31

third sector's voice 196

university-third sector partnerships 87

voice of the third sector 32, 196-197, 199-201, 208, 210-211

Townsend et al 43-45, 47, 49, 56

transdisciplinary 69, 71, 73, 133-134, 136-137

transformation $21,31,36,43,45,59,61$, $71,73,75,100-103,105-107$, $109-110,112,116,118,131$, $133,135,155,165-168,178$, 195-198, 200, 206, 210, 213, 235, 255-256, 291, 296-299, $302-303,305,307,310$

Treatment Action Campaign (TAC) 74, 78

trust $47,49,52-53,59,66,112,156$, 165-166, 172-174, 200, 261, 265, $271,287,301$

Tshwane Leadership Foundation 125, $137-138,141$

U

Ubuntu 164, 167

UCINET 226, 228, 231-232, 234

university

engaged university 28 university $26,28-29,31,34-37,41$, $51-52,60-64,66-70,72-78,81$, 87-90, 92, 96-99, 106-109, 111 , $117-118,132,134-135,137-141$, $159-161,167,170-171,173-174$, 176-178, 183, 194, 202, 207-208, 212-213, 224-226, 229, 234, 242, $250,254-257,263,265-266,269$, $272,279,288-289,291,296$, $301-304,308-310$

university actors 229

university-community collaboration 66

university-community interaction 66

university-community links 72

university-community partnerships 173 , 234

university-community relations 62

university degree 170

university expertise 70

university representatives 171

university research 74, 254

university staff 26, 63, 269, 272, 288

university students 138

university systems 31

university-third sector partnerships 87

\section{University}

African university $35,41,108,117,141$

International university rankings 109

Stellenbosch University (SU) 161

University of Botswana 137, 141

University of Cape Town (UCT) 242

University of Pretoria (UP) 27, 49, 67, 70-71, 82, 102, 112, 117, 120, 124-125, 135, 137-138, 140, 154, 156-157, 160, 166, 174, 183, 188, 205, 208, 213, 223, 238, 241-242, 262-263, 272, 277, 280, 284, 287, 309

University of Sheffield 254, 256-257, 265-266

University of South Africa (Unisa) 90-92, 96, 99 


\section{KNOWLEDGE AS ENABLEMENT}

University of the Free State (UFS) 23, $37,159-160,167,183,192,202$, $224-225,242,250,257,265,269$, 279-282, 289, 291, 293-295, 310

University of the Western Cape (UWC) 242 urban

local urban communities 136

urban 77-78, 97, 134, 136-140, 213, $219,238,241,252,267$

urban challenges 136,139

urban community 136

urban innovation hub 137, 140

urban studio 137-138

Utopia 104, 113, 116

Utopian 24, 100, 102-106, 110-111, 113, 115,118

V

values

clear values 125

democratic values 213

faith-based values 153

postcolonial values 266

religious values 152

shared values 129, 162, 165, 172-173, 176

values $33,75,86,88,125,129,135$, $145,148,152-153,155,157,162$, 164-167, 172-173, 176, 207, 213, 266, 297

vision $22,28,41,45,52,55,59,61,68$, $79,100,104,116,125,128-129$, $137,148,151,158-159,166-167$, $176,181,245,254,300$

volunteers 26, 55-56, 147, 149, 152-153, $156-158,160,176,180,186$, 188-189, 262, 265

Vygotsky 31, 297-298, 310

\section{W}

Waghid 29, 37

White Paper

Education White Paper 3 of 1997101

White Paper 23-24, 36, 61, 63, 78, 81, 98, 101-103, 106-108, 117-118, $165,178,196,213,218,224,235$, 303,310

White Paper for Post-School Education and Training of 201381

White Paper on the Transformation of Public Service of 1997196 


\section{ACRONYMS}

CDS Centre for Development Support

CE community engagement

CES community-engaged scholarship

CHE Council on Higher Education

CHESP Community - Higher Education - Service Partnerships

CPUT Cape Peninsula University of Technology

CSI Corporate Social Investment

CSR Corporate Social Responsibility

DETEA Department of Economic Development, Tourism and Environmental Affairs

DoE Department of Education

DoH Department of Health

DHET Department of Higher Education and Training

DoSD Department of Social Development

EL experiential learning

FGD focus group discussion

GEM Global Entrepreneurship Monitor

GIS Geographic Information System

GP global participant

HE higher education

HEI higher education institution

HEls higher education institutions

HoSL Head of Service Learning

IFC Industrial Finance Corporation

ILO International Labour Organization

ISTR International Society for Third-Sector Research

NPO non-profit organisation

NPOs non-profit organisations

NRF National Research Foundation

OECD Organization for Economic Cooperation and Development

OT Occupational Therapy

P participant

PAR participatory action research

ROC Reach Our Community (ROC) Foundation

SoN School of Nursing

SA South Africa

SL service learning

SNA social network analysis

SU Stellenbosch University

TAC Treatment Action Campaign

TS third sector

UCT University of Cape Town

UFS University of the Free State

UK United Kingdom

Unisa University of South Africa

UP University of Pretoria

UWC University of the Western Cape 